\title{
Supplementation of Vitamin E and C Reduces Oxidative Stress in Broiler Breeder Hens during Summer
}

\author{
B. P. Jena ${ }^{1}$, N. Panda ${ }^{1,2}$, R. C. Patra ${ }^{3 *}$, P. K. Mishra ${ }^{1}$, N. C. Behura ${ }^{1}$, B. Panigrahi ${ }^{4}$ \\ ${ }^{1}$ Department of Poultry Science, College of Veterinary Science and Animal Husbandry, Orissa University of Agriculture and Tech- \\ nology (OUAT), Bhubaneswar, India; ${ }^{2}$ Department of Animal Nutrition, College of Veterinary Science and Animal Husbandry, \\ Orissa University of Agriculture and Technology (OUAT), Bhubaneswar, India; ${ }^{3}$ Department of Veterinary Medicine, College of \\ Veterinary Science and Animal Husbandry, Orissa University of Agriculture and Technology (OUAT), Bhubaneswar, India; ${ }^{4}$ De- \\ partment of Livestock Production and Management, College of Veterinary Science and Animal Husbandry, Orissa University of \\ Agriculture and Technology (OUAT), Bhubaneswar, India. \\ Email: *rcpatra@gmail.com
}

Received March $14^{\text {th }}, 2013$; revised April 14 ${ }^{\text {th }}, 2013$; accepted April 21 $1^{\text {st }}, 2013$

Copyright (C) 2013 B. P. Jena et al. This is an open access article distributed under the Creative Commons Attribution License, which permits unrestricted use, distribution, and reproduction in any medium, provided the original work is properly cited.

\begin{abstract}
The present experiment was carried out to evaluate the effects of vitamin $\mathrm{E}$ and $\mathrm{C}$ supplementation on the antioxidant status of broiler breeder hens during summer. Two hundred seventy broiler breeder birds (coloured) were divided into nine groups with three replicates having 10 birds in each, and were supplemented two levels of antioxidant vitamins $\mathrm{E}$ ( $250 \mathrm{mg}$ or $500 \mathrm{mg} / \mathrm{kg}$ ) or C ( $200 \mathrm{mg}$ or $400 \mathrm{mg} / \mathrm{kg}$ ) alone or in combinations for a period of 8 weeks. All the vitamin supplemented groups showed significantly lowered malondialdehyde (MDA) level, higher activities of superoxide dismutase (SOD), catalase (CAT) enzymes and higher Ferric Reducing Antioxidant Power (FRAP) activities in erythrocytes than control. However, supplementation with combination of vitamins proved to be better than individual supplementation. It could be concluded that the combination of vitamins C and E at lower level (@ $200 \mathrm{mg} / \mathrm{kg}$ and $250 \mathrm{mg} / \mathrm{kg}$, respectively) had higher erythrocytic antioxidant status in coloured broiler breeder hens as compared to individual vitamin supplementation during hot and humid stress.
\end{abstract}

Keywords: Vitamin E; Vitamin C; Antioxidant Status; Hen; Summer

\section{Introduction}

Body temperature and metabolism rate of birds are relatively high compared to mammals, which make birds vulnerable to oxidative stress under high environmental temperature. High temperature coupled with humidity is more stressful that results major economic losses to the poultry industry by reducing growth, egg production, hatchability and increasing mortality. Heat stress not only adversely affects production performance but also inhibits immune function [1,2].

Vitamin $\mathrm{E}$ has been reported as an excellent biological chain-breaking antioxidant that protects cells and tissue from lipoperoxidative damage induced by free radicals. Vitamin C limits the metabolic signs of stress and alleviates the physiological consequences of stress, resulting in improved performance, immunological competence and

\footnotetext{
"Corresponding author.
}

behaviour of chickens. The antioxidative property of vitamin $\mathrm{E}$ in chickens is suggested to have significant role in the development of immune response through protection of the cells, such as lymphocytes, macrophages, and plasma cells from oxidative damages, and enhances the function and proliferation of these cells in face the oxidative stress [3,4]. Supplementation of vitamin E @ 250 mg alone has been reported to reduce the negative effects of heat stress in broilers [5]. Similarly, Panda et al. [6] concluded that dietary supplementation of vitamin C $(200 \mathrm{mg} / \mathrm{kg})$ improved antioxidant status in White Leghorn layer during summer stress. The synergistic effect of both the vitamins $\mathrm{E}$ and $\mathrm{C}$ was seen by Sahin et al. [7] in heat stressed laying Japanese quails as shown by decreased concentration of MDA in the serum of the birds. The present experiment is planned to evaluate the supplementation of both vitamin $\mathrm{E}$ and $\mathrm{C}$ either alone or in combination in the coloured broiler during hot and humid stress. 


\section{Materials and Methods}

\subsection{Experimental Animals and Feeding}

A total number of two hundred seventy $(n=270)$ synthetic coloured broiler breeder hens of 40 weeks old maintained at Faculty of Veterinary Science and Animal Husbandry Farm were used for the present experiment. The birds were randomly distributed into nine groups with three replicates having 10 birds in each replicate. The birds were kept in individual cages. Two levels of vitamin C (L-Ascorbic acid) i.e. $200 \mathrm{mg}$ or $400 \mathrm{mg}$ and vitamin E (DL- $\alpha$-tocopherol acetate) i.e. $250 \mathrm{mg}$ or $500 \mathrm{mg}$ were supplemented either alone or in combinations with breeder basal diet to eight groups, keeping one group of non-supplemented birds as control. The supplementation was continued for a period of 8 weeks. Water was provided $a d$ lib. Daily feed given was weighed and supplied @ $150 \mathrm{~g} / \mathrm{bird} /$ day. In-house temperature and relative humidity was recorded daily during the experimental period and average values were calculated (Figures $\mathbf{1}$ and 2). Feeds samples were analysed for moisture, crude protein, ether extract, crude fibre, total ash, and acid insoluble ash (Table 1) as per A.O.A.C [8].

\subsection{Experimental Design and Feeding Levels}

\begin{tabular}{|c|c|}
\hline Group & Feeding level of vitamins \\
\hline $\mathrm{T}_{1}$ & Basal diet (without supplementation) \\
\hline $\mathrm{T}_{2}$ & Basal diet + vitamin C @ 200 mg/kg feed \\
\hline $\mathrm{T}_{3}$ & Basal diet + vitamin C @ 400 mg/kg feed \\
\hline $\mathrm{T} 4$ & Basal diet + vitamin E @ 250 mg/kg feed \\
\hline T5 & Basal diet + vitamin E @ 500 mg/kg feed \\
\hline T6 & $\begin{array}{l}\text { Basal diet + vitamin C @ } 200 \text { mg } / \mathrm{kg} \\
\text { feed + vitamin E @ } 250 \text { mg } / \mathrm{kg} \text { feed }\end{array}$ \\
\hline $\mathrm{T} 7$ & $\begin{array}{l}\text { Basal diet + vitamin C @ } 200 \text { mg } / \mathrm{kg} \\
\text { feed + vitamin E @ } 500 \text { mg } / \mathrm{kg} \text { feed }\end{array}$ \\
\hline T8 & $\begin{array}{l}\text { Basal diet + vitamin C @ } 400 \text { mg } / \mathrm{kg} \\
\text { feed + vitamin E @ } 250 \text { mg } / \mathrm{kg} \text { feed }\end{array}$ \\
\hline T9 & $\begin{array}{l}\text { Basal diet + vitamin E @ } 400 \text { mg } / \mathrm{kg} \\
\text { feed + vitamin E @ } 500 \text { mg } / \mathrm{kg} \text { feed }\end{array}$ \\
\hline
\end{tabular}

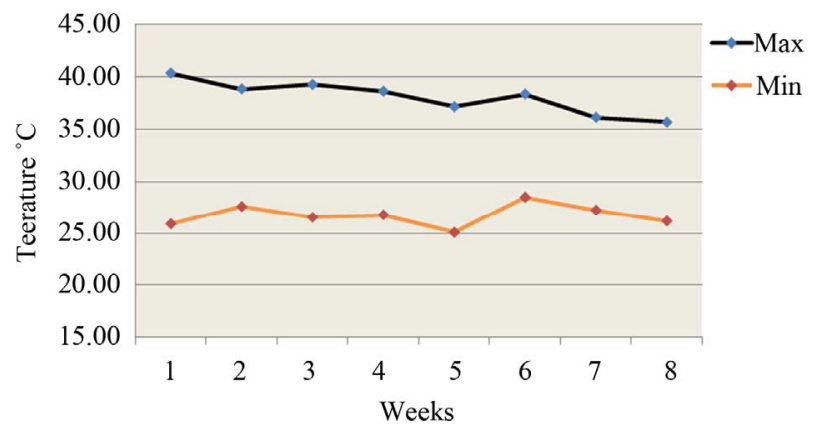

Figure 1. Variation of in house temperature during experimental period.

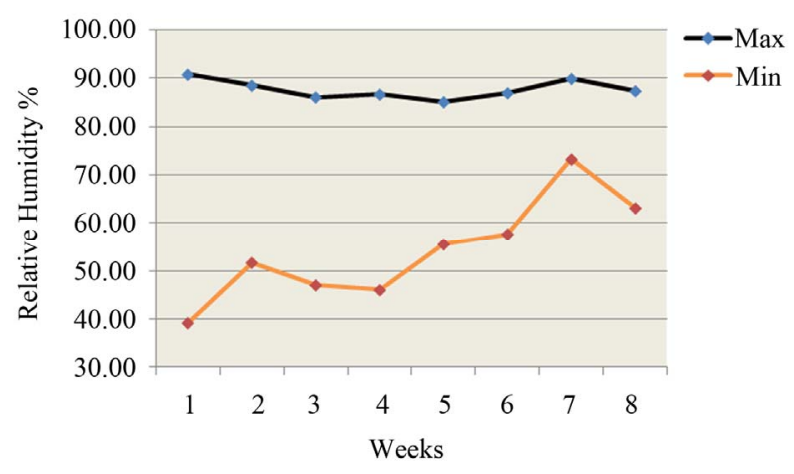

Figure 2. Average relative humidity during experimental period.

Table 1. Composition of basal diet and proximate composition of experimental rations.

\begin{tabular}{|c|c|c|c|}
\hline $\begin{array}{l}\text { Ingredients } \\
\text { (Kg) }\end{array}$ & Percentage & $\begin{array}{c}\text { Proximate } \\
\text { composition }\end{array}$ & $\begin{array}{c}\text { Percentage on } \\
\text { DM basis }\end{array}$ \\
\hline Maize & 52 & Moisture & 9.24 \\
\hline Soyabean meal & 29 & Crude protein & 18.01 \\
\hline $\begin{array}{l}\text { De oiled } \\
\text { Rice bran }\end{array}$ & 11 & Ether extract & 4.16 \\
\hline $\begin{array}{l}\text { Mineral } \\
\text { mixture }\end{array}$ & 03 & Crude fibre & 4.92 \\
\hline $\begin{array}{l}\text { Oyster shell } \\
\text { meal }\end{array}$ & 4.5 & Total ash & 10.54 \\
\hline Common salt & 0.3 & $\begin{array}{c}\text { Acid } \\
\text { insoluble ash }\end{array}$ & 2.66 \\
\hline L-Lysine & 0.05 & $\begin{array}{c}\text { Nitrogen free } \\
\text { extract }^{*}\end{array}$ & 53.82 \\
\hline DL-methionine & 0.05 & Calcium & 2.97 \\
\hline Tracemin & 0.1 & $\begin{array}{c}\text { Available } \\
\text { phosphorus }\end{array}$ & 0.57 \\
\hline \multicolumn{2}{|c|}{ Feed additives used (g/kg diet) } & $\begin{array}{c}\text { Metabolisable } \\
\text { energy } \\
\text { * (Kcal/kg) }\end{array}$ & 2805 \\
\hline $\begin{array}{l}\text { Biobloom } \\
\text { (probiotic) }\end{array}$ & 0.5 & Lysine $^{*}$ & 1.39 \\
\hline $\begin{array}{c}\text { Vilocym-z } \\
\text { (toxin binder) }\end{array}$ & 1.0 & Methionine $^{*}$ & 0.64 \\
\hline $\begin{array}{l}\text { Ayufytase } \\
5000 \text { (phytase } \\
\text { enzyme) }\end{array}$ & 0.1 & & \\
\hline $\begin{array}{l}\text { K-live } \\
\text { (liver } \\
\text { stimulant) }\end{array}$ & 1.0 & & \\
\hline $\begin{array}{l}\text { Ventrimix } \\
\text { (vitamin } \\
\text { premix) }\end{array}$ & 0.1 & & \\
\hline
\end{tabular}

"Calculated value.

\subsection{Oxidative Stress Indices}

Blood samples were collected from wing vein into sterile 
test tubes with anticoagulant EDTA from 9 birds (3 birds from each replicate) of each treatment group on $4^{\text {th }}$ and $8^{\text {th }}$ week of experiment for obtaining packed RBC to estimate erythrocytic MDA concentration and antioxidant enzymes.

Membrane peroxidative damage in the erythrocytes was determined in terms of malondialdehyde (MDA) production by the method described by Placer et al. [9]. The superoxide dismutase (SOD) activity in 10\% RBC hemolysate was measured following the methods of Marklund and Marklund [10] with certain modification [11]. The estimation of catalase activity in 10\% RBC hemolysate was done as per the procedure described by Cohen et al. [12]. Plasma total antioxidant activity was measured at $4^{\text {th }}$ and $8^{\text {th }}$ week of experiment by ferric reducing antioxidant power (FRAP) assay [13].

\subsection{Statistical Analysis}

The data obtained from the study were statistically analyzed according to Snedecor and Cochran [14]. The data were also analyzed for analysis of variance (ANOVA) and DMR test [15] was used to test the difference between treatment means wherever necessary.

\section{Results}

\subsection{Lipid Peroxidation Status}

The MDA values varied from 4.23 to 6.37 and 3.59 to $8.86 \mathrm{nmol} / \mathrm{mg} \mathrm{Hb}$ at $4^{\text {th }}$ and $8^{\text {th }}$ week respectively (Table 2). At $4^{\text {th }}$ week, the MDA concentration was significantly ( $\mathrm{p}<0.01$ ) lower in combined vitamin supplemented groups $\left(\mathrm{T}_{6}-\mathrm{T}_{9}\right)$ than control and individual vitamin supplemented groups. Whereas by $8^{\text {th }}$ week, all the supple- mented groups showed significantly lower value than control but no significant difference was observed between the vitamins supplemented groups either alone or in combination. Comparing the concentration of MDA between both the weeks in different treatments, there was significant ( $p<0.01$ ) increase of MDA concentration in control group only at $8^{\text {th }}$ week with respect to $4^{\text {th }}$ week.

\subsection{Superoxide Dismutase}

The status of enzymatic antioxidants in erythrocytes of broiler breeders at $4^{\text {th }}$ and $8^{\text {th }}$ week of study revealed that after $4^{\text {th }}$ week, the erythrocyte SOD enzyme activity (U/mg Hb) of $T_{5}$ (E500) and $T_{6}$ to $T_{9}$ (all combined vitamin supplemented groups) were significantly ( $p<0.05$ ) higher than the control group (Table 2). No significant difference was evident between the control and $T_{2}, T_{3}$ and $\mathrm{T}_{4}$. However at $8^{\text {th }}$ week, the SOD activity was significantly higher $(\mathrm{p}<0.05)$ in the all supplemented groups than control. Moreover, SOD activity at $8^{\text {th }}$ week was found to be significantly $(\mathrm{p}<0.05)$ higher than that of $4^{\text {th }}$ week in $\mathrm{T}_{3}$ and all combined vitamin supplemented groups.

\subsection{Catalase}

In the present study, catalase activity was significantly (p $<0.05$ ) higher in vitamin supplemented groups (except $\mathrm{T}_{2}$-C200) than control at $4^{\text {th }}$ week (Table 2). However, after 8 weeks of feeding all supplemented groups showed significantly $(\mathrm{p}<0.05)$ higher catalase activity than control and all combined supplemental groups showed significantly higher values than individual vitamin supplemented groups. Comparison between the weeks for all groups showed that there was significant $(p<0.05)$ de-

Table 2. Oxidative stress indices and antioxidant capacity of plasma in different groups.

\begin{tabular}{|c|c|c|c|c|c|c|c|c|c|}
\hline \multirow{2}{*}{ Groups } & \multirow{2}{*}{$\begin{array}{c}\text { Vitamin/ } \\
\text { dose }(\mathrm{mg} / \mathrm{kg})\end{array}$} & \multicolumn{2}{|c|}{$\begin{array}{l}\text { MDA concentration } \\
\text { (nmol/mg Hb) }\end{array}$} & \multicolumn{2}{|c|}{$\begin{array}{c}\text { SOD } \\
\text { (U/mg Hb) }\end{array}$} & \multicolumn{2}{|c|}{$\begin{array}{l}\text { CATALASE } \\
\text { (U/mg Hb) }\end{array}$} & \multicolumn{2}{|c|}{$\begin{array}{c}\text { FRAP value of } \\
\text { plasma }(\mu \mathrm{mol} / \text { litre })\end{array}$} \\
\hline & & $4^{\text {th }}$ week & $8^{\text {th }}$ week & $4^{\text {th }}$ week & $8^{\text {th }}$ week & $4^{\text {th }}$ week & $8^{\text {th }}$ week & $4^{\text {th }}$ week & $8^{\text {th }}$ week \\
\hline $\mathrm{T}_{1}$ & Control & $6.37^{\mathrm{aB}} \pm 0.16$ & $8.86^{\mathrm{aA}} \pm 0.36$ & $2.88^{b} \pm 0.19$ & $2.40^{\mathrm{d}} \pm 0.25$ & $0.25^{\mathrm{dA}} \pm 0.02$ & $0.17^{\mathrm{fB}} \pm 0.01$ & $1312.56^{\mathrm{eB}} \pm 27.82$ & $1414.77^{\mathrm{cA}} \pm 7.43$ \\
\hline $\mathrm{T}_{2}$ & C200 & $5.54^{\mathrm{abc}} \pm 0.18$ & $4.96^{\mathrm{b}} \pm 0.61$ & $3.48^{\mathrm{ab}} \pm 0.35$ & $4.15^{\mathrm{c}} \pm 0.57$ & $0.34^{\mathrm{cd}} \pm 0.03$ & $0.43^{\mathrm{e}} \pm 0.04$ & $1471.03^{\mathrm{dB}} \pm 24.09$ & $1594.30^{\mathrm{bA}} \pm 15.57$ \\
\hline $\mathrm{T}_{4}$ & E250 & $5.57^{\mathrm{ab}} \pm 0.29$ & $4.67^{\mathrm{b}} \pm 0.45$ & $3.56^{\mathrm{ab}} \pm 0.17$ & $4.26^{\mathrm{bc}} \pm 0.38$ & $0.39^{\mathrm{cB}} \pm 0.04$ & $0.61^{\mathrm{dA}} \pm 0.04$ & $1587.67^{\mathrm{bcB}} \pm 6.64$ & $1677.18^{\mathrm{bA}} \pm 44.45$ \\
\hline $\mathrm{T}_{5}$ & E500 & $5.31^{\mathrm{abcd}} \pm 0.31$ & $4.66^{\mathrm{b}} \pm 0.26$ & $3.85^{\mathrm{a}} \pm 0.36$ & $4.88^{\mathrm{abc}} \pm 0.37$ & $0.46^{\mathrm{bcB}} \pm 0.05$ & $0.66^{\mathrm{dA}} \pm 0.05$ & $1636.97^{\mathrm{bB}} \pm 17.85$ & $1705.15^{\mathrm{bA}} \pm 40.21$ \\
\hline $\mathrm{T}_{6}$ & C200 + E250 & $4.23^{d} \pm 0.43$ & $3.59^{\mathrm{b}} \pm 0.41$ & $4.33^{\mathrm{aB}} \pm 0.24$ & $6.11^{\mathrm{aA}} \pm 0.41$ & $0.61^{\mathrm{aB}} \pm 0.03$ & $1.05^{\mathrm{abA}} \pm 0.04$ & $1746.96^{\mathrm{aB}} \pm 12.19$ & $1915.02^{\mathrm{aA}} \pm 20.09$ \\
\hline $\mathrm{T}_{7}$ & $\mathrm{C} 200+\mathrm{E} 500$ & $4.39^{\mathrm{cd}} \pm 0.45$ & $3.65^{b} \pm 0.45$ & $4.04^{\mathrm{aB}} \pm 0.06$ & $5.90^{\mathrm{abA}} \pm 0.16$ & $0.54^{\mathrm{abB}} \pm 0.02$ & $0.94^{\mathrm{bcA}} \pm 0.02$ & $1748.99^{\mathrm{aB}} \pm 20.04$ & $1920.00^{\mathrm{aA}} \pm 8.80$ \\
\hline $\mathrm{T}_{9}$ & $\mathrm{C} 400+\mathrm{E} 500$ & $4.57^{\mathrm{bcd}} \pm 0.16$ & $3.79^{\mathrm{b}} \pm 0.28$ & $4.02^{\mathrm{aB}} \pm 0.07$ & $5.87^{\mathrm{abA}} \pm 0.14$ & $0.67^{\mathrm{aB}} \pm 0.01$ & $1.17^{\mathrm{aA}} \pm 0.04$ & $1752.83^{\mathrm{aB}} \pm 20.60$ & $1921.67^{\mathrm{aA}} \pm 32.44$ \\
\hline
\end{tabular}

${ }^{\mathrm{a}, \mathrm{b}}$ Means with no common superscript within a column vary significantly $(\mathrm{P}<0.05) .{ }^{\mathrm{A}, \mathrm{B}}$ Means with no common superscript within a row vary significantly $(\mathrm{P}<$ $0.05)$. 
crease in catalase level in control after 8 weeks exposure to heat stress. The catalase activity improved significantly $(\mathrm{p}<0.05)$ for group $\mathrm{T}_{4}$ to $\mathrm{T}_{9}$ between $4^{\text {th }}$ and $8^{\text {th }}$ week.

\subsection{Total Antioxidant Capacity}

The total antioxidant capacity of the plasma in 9 groups at $4^{\text {th }}$ week of the experiment varied from 1312.56 (control) to $1752.83\left(\mathrm{~T}_{9}\right)$ and after $8^{\text {th }}$ week it was 1363.67 (control) to 1837.25 $\left(\mathrm{T}_{9}\right)$ (Table 2). The highest values were observed in $\mathrm{T}_{9}(\mathrm{C} 400+\mathrm{E} 500)$ at the both weeks. At both $4^{\text {th }}$ and $8^{\text {th }}$ week all vitamin supplemented groups showed significantly $(\mathrm{p}<0.05)$ higher FRAP value than control and among supplemented groups, combined supplemented groups had significantly higher FRAP values than individual vitamin supplemented groups. There was no significant difference among combined supplemental groups.

\section{Discussion}

As environmental temperature increases, hens' respiration and evaporation increases to maintain optimal body temperature, which in turn increases their metabolism and energy consumption. If increased energy needs is not supplied with feed (less feed consumption during heat stress), mobilisation of lipids from stored fat takes place. The MDA level, an indicator of lipid peroxidation, increases with increases in lipid mobilization and oxidation of lipids. Level of erythrocyte MDA continued to rise in hens exposed to heat stress (control) and hens fed rations containing vitamin $\mathrm{C}$ and $\mathrm{E}$ separately or as combinations showed significantly lower MDA level. Continuous feeding of both the antioxidant vitamins for two months during summer stress decreased the MDA concentration from its level recorded at one month. This result is in accordance with the earlier findings [1,6,16,17]. Similar result was also observed in serum and liver MDA concentration [18] in ascorbic acid and melatonin supplemented birds. The observed decrease in erythrocyte MDA levels in the groups supplemented with vitamin $\mathrm{E}$ and $\mathrm{C}$ might have been due to the inhibition of lipid peroxidation in erythrocyte membranes due to the antioxidant effect of both the vitamins. This study suggests that lipid peroxides formed under heat stress conditions can be partially counteracted by dietary inclusion of antioxidants such as vitamin $\mathrm{E}$ and $\mathrm{C}$.

The results of SOD activity is in accordance with the earlier reports $[19,20,21]$ who found significant increase in SOD activities of vitamin supplemented groups compared to control. It is suggested that antioxidant vitamin supplementation during heat stress enhances SOD activity to minimize oxidative stress in chicken by inhibiting the oxygen free radical production and scavenging the superoxide ions [22]. As the stress period increased the enzyme activity at $4^{\text {th }}$ week in control and individual vitamin supplemented groups were similar but decreased further at $8^{\text {th }}$ week in control group whereas upward trend was observed in all supplemented groups. The result also clearly explains the synergistic effect of both the vitamins $[7,16]$.

In the cell, catalase reacts with generated hydrogen peroxide to form water and molecular oxygen thereby protecting the cells against hydrogen peroxide toxicity and lipid peroxidation [23]. Erythrocyte CAT levels in the supplemented groups under heat stress demonstrated an increasing trend, as compared to the control group that is well supported by the findings of others $[6,20,24]$. Only $\mathrm{T}_{2}$ group did not show any difference of CAT status in comparison to control at $4^{\text {th }}$ week but with continuous feeding for 8 weeks significant difference was observed. This might be due to the lower level of vitamin C, which was not enough to neutralise the hydrogen peroxide radicals produced during continuous heat stress period. The combined vitamin supplemented groups showed significantly higher values than vitamins fed alone, might be due to synergistic effect of vitamin $\mathrm{C}$ and $\mathrm{E}$ on scavenging free radicals and hydrogen peroxides. The increase in the activities of erythrocytic SOD and catalase enzymes led to an increased defence of cell membranes against oxygen and free radicals. These cooperative antioxidant defence mechanisms minimized oxidative damage. Higher enzymatic activity along with lower level of MDA concentration indicated better antioxidant status of the birds supplemented with vitamin $\mathrm{C}$ and $\mathrm{E}$ either individually or in combinations.

Significantly higher FRAP values in vitamin supplemented groups at both $4^{\text {th }}$ and $8^{\text {th }}$ week indicates better antioxidant status of the plasma. The result provides the measure of combined non-enzymatic antioxidant defence capacity of plasma and gives an index of ability to resist oxidative damage. Birds of group $\mathrm{T}_{9}(\mathrm{C} 400+\mathrm{E} 500)$ showed highest antioxidant capacity probably due to higher plasma vitamin $\mathrm{E}$ and $\mathrm{C}$ concentration after 4 weeks of vitamin supplementation. No literature was available that uses FRAP assay to measure the total antioxidant capacity of the plasma in poultry birds to substantiate our findings. However, increase in the antioxidant status of the birds by supplementation of vitamin $\mathrm{C}$ and $\mathrm{E}$ have been reported by other workers $[2,18,20]$.

\section{Conclusion}

The study suggests that combination of vitamins at lower level (C200 + E250 mg/kg feed) has beneficial effect on antioxidant status of coloured broiler breeder hens during natural hot and humid stress as higher level of the vitamins don't impart any significant improvement the lower level. 


\section{REFERENCES}

[1] U. Puthpongsiriporn, S. E. Scheideler, J. L. Sell and M. M. Beck, "Effects of Vitamin E and C Supplementation on Performance, in Vitro Lymphocyte Proliferation, and Antioxidant Status of Laying Hens During Heat Stress,” Poultry Science, Vol. 80, No. 8, 2001, pp. 1190-1200.

[2] A. K. Panda, S. V. Ramarao, M. V. L. N. Raju and R. N. Chatterjee, "Effect of Dietary Supplementation with Vitamins E And C on Production Performance, Immune Responses and Antioxidant Status of White Leghorn Layers under Tropical Summer Conditions," British Poultry Science, Vol. 49, No. 5, 2008, pp. 592-599.

doi:10.1080/00071660802337233

[3] A. Franchini, M. Canti, G. Manfreda, S. Bertuzzi, G. Asdrubali and C. Franciosi, "Vitamin E as Adjuvant in Emulsified Vaccine for Chicks,” Poultry Science, Vol. 70, No. 8, 1991, pp. 1709-1715. doi:10.3382/ps.0701709

[4] S. N. Meydani and J. B. Blumberg, "Vitamin E and the Immune Response,” In: S. Cunningham-Rundles, Ed., $\mathrm{Nu}$ trient Modulation of the Immune Response, Marcel Dekker, New York, 1993, pp. 223-238.

[5] K. Sahin, N. Sahin, M. Onderci, S. Yaralioglu and O. Kucuk, "Protective Role of Supplemental Vitamin E on Lipid Peroxidation, Vitamin E, A and Some Mineral Concentrations of Broilers Reared under Heat Stress," Veterinaria Medicinia-Czech, Vol. 46, No. 5, 2001, pp. 140-144.

[6] A. K. Panda, S. V. Ramarao and M. V. L. N. Raju, "Effect of Vitamin C Supplementation on Performance, Immune Response and Antioxidant Status of Heat Stressed White Leghron Layers," Indian Journal of Poultry Science, Vol. 42, No. 2, 2007, pp. 169-173.

[7] K. Sahin, N. Sahin, M. Onderci, M. F. Gursu and M. Issi, "Vitamin C and E Can Alleviate Negative Effects of Heat Stress in Japanese Quails,” Food, Agriculture and Environment, Vol. 1, No. 2, 2003, pp. 244-249.

[8] A.O.A.C., "Official Methods of Analysis, Association of Official Analytical Chemists,” 13th Edition, PO Box NO540, Benjamin Franklin Station, Washington DC, 1995.

[9] Z. A. Placer, L. Cushman and B. Johnson, "Estimation of Products of Lipid Peroxidation (MDA) in Biochemical System," Analytical Biochemistry, Vol. 16, No. 2, 1966, pp. 359-364. doi:10.1016/0003-2697(66)90167-9

[10] S. Marklund and G. Marklund, "Involvement of Superoxide Anion Radical in the Autooxidation of Pyrogallol and a Convenient Assay for SOD," European Journal of Biochemistry, Vol. 47, No. 3, 1974, pp. 464-474. doi:10.1111/j.1432-1033.1974.tb03714.x

[11] M. Menami and H. Yoshikawa, "Simplified Assay Method of SOD Activity of Clinical Use," Clinica Chimica Acta, Vol. 92, No. 3, 1979, pp. 337-342. doi:10.1016/0009-8981(79)90211-0

[12] G. Cohen, D. Dembiec and J. Marens, "Measurement of Catalase Activity in Tissue Extracts," Analytical Biochemistry, Vol. 34, No. 1, 1970, pp. 30-38. doi:10.1016/0003-2697(70)90083-7

[13] F. F. Benzie and J. J. Strain, "Ferric Reducing Antioxidant Power Assay: Direct Measure of Total Antioxidant
Activity of Biological Fluids and Modified Version of Simultaneous Measurement of Total Antioxidant Power and Ascorbic Acid Concentration," Methods in Enzymology, Vol. 299, No. 1, 1999, pp. 15-23. doi:10.1016/S0076-6879(99)99005-5

[14] G. W. Snedecor and W. G. Cochran, "Statistical Methods," 8th Edition, Lowa State University Press, Ames, lowa, 1994.

[15] D. B. Duncan, "Multiple Ranges and Multiple F Test," Biometrics, Vol. 11, No. 1, 1955, pp. 1-42. doi: $10.2307 / 3001478$

[16] K. Sahin, N. Sahin and S. Yaralioglu, "Effects of Vitamin $\mathrm{C}$ and Vitamin E on Lipid Peroxidation, Blood Serum Metabolites and Mineral Concentrations of Laying Hens Reared at High Ambient Temperature,” Biological Trace Element Research, Vol. 85, No. 1, 2002, pp. 35-45. doi:10.1385/BTER:85:1:35

[17] Y. F. Lin, H. L. Tsai, Y. C. Lee and S. J. Chang, "Maternal Vitamin E Supplementation Affects the Antioxidant Capability and Oxidative Status of Hatching Chicks," Journal of Nutrition, Vol. 135, No. 10, 2005, pp. 24572461.

[18] N. Sahin, M. Onderci, K. Sahin, M. F. Gursu and M. O. Smith, "Ascorbic Acid and Melatonin Reduce Heat-Induced Performance Inhibition and Oxidative Stress in Japanese Quails,” British Poultry Science, Vol. 45, No. 1, 2004, pp. 116-122. doi:10.1080/00071660410001668941

[19] K. Z. Mahmoud and A. A. Hijazi, "Effect of Vitamin A and/or E on Plasma Enzymatic Antioxidant Systems and Total Antioxidant Capacity of Broiler Chickens Challenged with Carbon Tetrachloride," Journal of Animal Physiology and Animal Nutrition, Vol. 91, No. 7-8, 2007, pp. 333-340. doi:10.1111/j.1439-0396.2006.00659.x

[20] Y. Eid, T. Ebeid, M. Moawad and M. El-Habbak, "Reduction of Dexamethasone-Induced Oxidative Stress and Lipid Peroxidation in Laying Hens by Dietary Vitamin E Supplementation," Emirates Journal of Food and Agriculture, Vol. 20, No. 2, 2008, pp. 28-40.

[21] V. Sujatha, J. P. Korde, S. K. Rastogi, S. Maini, K. Ravikanth and D. S. Rekhe, "Amelioration of Heat Stress Induced Disturbances of the Antioxidant Defence System in Broilers," Journal of Veterinary Medicine and Animal Health, Vol. 2, No. 3, 2010, pp. 18-28.

[22] R. Ozturk-urek, L. A. Bozkayaa and L. Tarhan, "The Effect of Some Antioxidant Vitamin and Trace ElementSupplemented Diets on Activities of SOD, CAT, GSH-Px and LPO Levels in Chicken Tissues," Cell Biochemistry Function, Vol. 19, No. 2, 2001, pp. 125-132. doi:10.1002/cbf.905

[23] S. Yamaguchy, “The Role of SOD an Antioxidant,” Journal of National Cancer Institute, Vol. 28, No. 3, 1991, pp. 221-232.

[24] H. Yardibi and G. Turkay, "The Effects of Vitamin E on the Antioxidant System, Egg Production, and Egg Quality in Heat Stressed Laying Hens," Turkish Journal of Veterinary and Animal Science, Vol. 32, No. 5, 2008, pp. 319-325. 